\title{
Equine cutaneous pythiosis: a report of four cases
}

\author{
Pitiose cutânea eqüina: um relato de quatro casos
}

Selwyn Arlington Headley ${ }^{1}$ Homero Neves Arruda Junior ${ }^{2}$

- RELATO DE CASO -

\section{ABSTRACT}

Cutaneous pythiosis is described in four horses in Northern Paraná, Brazil. All animals presented ulcerative, granulomatous, cutaneous lesions that did not invade adjacent muscular tissues. Histopathological evaluations revealed eosinophilic granulomatous reactions associated with intralesional hyphae suggestive of Pythium insidiosum observed at the margins of coagula. P. insidiosum hyphae were visualized by Gomori's methenamine silver stain.

Key words: pythiosis; Pythium insidiosum; horses.

RESUMO

Descreve-se pitiose cutânea em quatro cavalos no norte de Paraná, Brasil. Os animais apresentaram lesões cutâneas, ulcerativas e granulomatosas que não alcançaram o tecido muscular adjacente. Avaliação histopatológica revelou reação granulomatosa eosinofílica associada a hifas intralesionais sugestivas de Pythium insidiosum. As hifas de $\boldsymbol{P}$. insidiosum foram observadas na coloração especial de prata de Gomori.

Palavras-chave: pitiose, Pythium insidiosum; eqüinos.

\section{INTRODUCTION}

Equine cutaneous pythiosis is an invasive, ulcerative, granulomatous, tumor-like lesion caused by the aquatic fungus-like pathogen Pythium insidiosum (CHAFFIN et al., 1995; MENDOZA et al., 1996). Equine pythiosis occurs in tropical, semitropical, and temperate countries (MENDOZA et al., 1996; PIER et al., 2000), and has been well described in several Brazilian States (LEAL et al., 2001a). Pyhtiosis has been described in cats (THOMAS \& LEWIS, 1998), dogs (BENTINCK-SMITH et al., 1989; THOMAS \& LEWIS, 1998), cattle (SANTURIO et al., 1998), and humans (THITITHANYANONT et al., 1998).

$\boldsymbol{P}$. insidiosum-associated equine lesions occur more frequently in the skin and subcutaneous tissues than in other anatomic locations (CHAFFIN et al. 1995; PIER, et al., 2000). However, atypical (LEAL et al., 2001b) and intestinal (CHAFFIN et al., 1995) forms of equine pythiosis have been described. The development of cutaneous lesions is directly related to the parts of the body that are in direct contact with aquatic zoospores of $\boldsymbol{P}$. insidiosum (MENDOZA et al., 1996), which explains the frequent occurrence of lesions on the distal extremities, and the ventral regions of the thorax and the abdomen.

This report describes four cases of equine cutaneous pythiosis diagnosed by Gomori's methenamine silver stain in horses that were submitted for slaughter by the Federal Inspection Service in Northern Paraná. This article contributes to a better epidemiological understanding of the rising number of equine pythiosis that is being diagnosed in various Brazilian States, suggesting that equine pythiosis is probably endemic throughout Brazil.

${ }^{1}$ Médico Veterinário, Mestre, Docente, Laboratório de Patologia Veterinária, Centro Universitário de Maringá (CESUMAR), Av. Guedner 1610, Jd. Aclimação, 87050-390, Maringá, PR, Brasil. E-mail: headleysa@ @esumar.br Autor para correspondência.

${ }^{2}$ Médico Veterinário, Serviço de Inspeção Federal, Santa Fé, PR. 


\section{CASE REPORTS}

The first case (Protocol $N^{\circ}$ CMh 25/2002) was a mixed breed, five-year-old mare from the city of Itapeva, São Paulo, submitted for slaughter during midJune 2002. The animal was in poor body condition during the external pre-slaughter examination. She presented a large $(12 \times 15 \mathrm{~cm})$ ulcerated elevated granulomatous mass, located on the lateral surface of the left forelimb just above the elbow joint; a seroussanguineous secretion was observed oozing from the mass. The second case (Protocol $\mathrm{N}^{\circ} \mathrm{CMh} 44 / 2002$ ) was a mixed-breed, adult mare from the city of Campo Mourão, Paraná, submitted for slaughter during early August 2002. The animal was in regular body condition and presented a large $(10 \times 15 \mathrm{~cm})$ ulcerated mass at the lateral surface of the right forelimb just below the elbow joint. The third case (Protocol $\mathrm{N}^{\circ} \mathrm{CMh} 47 / 2002$ ) was a, mixed-breed mare of uncertain age that originated from Araçatuba, São Paulo; submitted for slaughter in mid August 2002. She also presented a large $(8 \times 10 \mathrm{~cm})$ ulcerated mass on the left forelimb. The last case (Protocol $\mathrm{N}^{\circ} \mathrm{CMh} 53 / 2002$ ) was a mixed breed horse from the city of Lobato, PR, submitted to slaughter in late August 2002. This animal was in regular body condition and presented a $10 \times 15$ ulcerated, granulomatous mass on the left forelimb. All animals were isolated for necropsy. Tissues were fixed in $10 \%$ formalin solution and processed for routine histopathological evaluation; selected sections were stained by the Gomori's methenamine silver (GMS) staining method.

\section{RESULTS AND DISCUSSION}

Gross evaluation of the first horse (Protocol $\mathrm{N}^{\circ} \mathrm{CMh} 25 / 2002$ ), revealed that the affected area was well demarcated and restricted to the subcutaneous conjunctive tissue. Deep muscular tissues were not affected. Several layers of yellowish material (kunkers) were observed in necrotic tissues. Transverse sections of the tissue revealed irregular, necrotic areas (0.3 $1.5 \mathrm{~cm}$ de diameter) forming various fistulous tracts with kunkers in the center. Most necrotic centers were surrounded by fibrous tissue and presented more than one kunker. Histopathological evaluation revealed extensive necrosis of superficial epithelial tissues associated with a marked inflammatory influx of neutrophils, perivascular edema, and various extremely eosinophilic areas within the underlying dermis. These eosinophilic areas were composed of dead or degenerated eosinophils admixed with cellular debris, collagen, and marginally located $\boldsymbol{P}$. insidiosum hyphae.
Marginally located hyphae (measuring between 3.5$5.5 \mu \mathrm{m}$ in diameter) were negatively stained by Hematoxlyin and Eosin, but were easily identified by GMS stain. Few hyphae were septated and some were branched; branching hyphae formed right angles. Between adjacent eosinophilic masses there was marked proliferation of connective tissue, moderate to severe proliferation of newly formed vessels, and an intense influx of eosinophils.

The gross and histopathological alterations of the other three cases were similar to the case previously described, having eosinophilic masses surrounded by an intense granulomatous reaction. Vascular alterations, such as thrombosis of larger vessels, observed only in the second case (Protocol $\mathrm{N}^{\circ}$ CMh 44/2002), and mild to severe vascular proliferation (present in all cases) associated with intralesional hyphae stained by the GMS method were the principal histopathological changes.

The cutaneous alterations described in this report are highly suggestive of lesions induced by $\boldsymbol{P}$. insidiosum in horses (MILLER \& CAMPBELL, 1984; CHAFFIN et al., 1995; MENDOZA et al., 1996). Although isolation, or other more sensitive identification methods, was not utilized in this report to definitely characterize the pathogen, the finding of kunkers, and right angled, thick walled, $2.5-8.5 \mu \mathrm{m}$ in diameter hyphae associated with eosinophilic granulomatous reaction observed by GMS staining are strong evidences to diagnose pythiosis by histopathology (MILLER \& CAMPBELL, 1984; MENDOZA et al., 1996). However, in a recent immunohistochemical study $17 \%$ (6/34) of the cases previously diagnosed as pyhtiosis by GMS staining were negative for $\boldsymbol{P}$. insidiosum by immunohistochemistry (REIS JR \& NOGUEIRA, 2002). Therefore, histopathological diagnosis of pyhtiosis based exclusively on GMS staining and morphological characteristics of the fungus, as described in this study, are not sufficient to furnish a definite diagnosis of $\boldsymbol{P}$. insidiosum, but are strong presumptive indications of lesions induced by this agent. Consequently, differential diagnosis with other similar morphological fungal agents must be considered in cases where diagnosis is based only on histopathology.

Basidiobolomycosis and condiobolomycosis are cutaneous granulomatous mycotic infections caused by Basidiobolus haptosporus and Condiobolus coronatus, respectively, and may be easily confused with pythiosis (MILLER \& CAMPBELL, 1984). However, there are morphological and anatomic characteristics that could be used in an 
attempt to differentiate these cutaneous mycotic lesions. Of the two-abovementioned diseases, basidiobolomycosis is more similar to pythiosis clinically, occurring in almost the same anatomic locations (MILLER \& CAMPBELL, 1984; MENDOZA et al., 1996). However, microscopically, basidiobolomycosis is considered more edematous, while pythiosis is highly fibrotic (MILLER \& CAMPBELL, 1984), as was observed in this report. Lesions of condiobolomycosis are reportedly restricted almost exclusively to the nasal region (MILLER \& CAMPBELL, 1984; MENDOZA et al., 1996), all cases described in this report occurred on the extremities. The size of the fungal hyphae is of particular importance in histopathological diagnosis, and could be fundamental to differentiate these three granulomatous cutaneous equine infections (MILLER \& CAMPBELL, 1984; MENDOZA et al., 1996). Comparatively, hyphae of $\boldsymbol{P}$. insidiosum are relatively small (2.6 - $6.4 \mu \mathrm{m}$ in diameter), $\boldsymbol{C}$. coronatus are

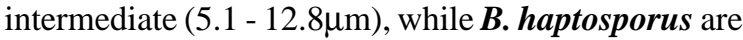
very large $(5.1-20.5 \mu \mathrm{m})$, so the size of intralesional hyphae could aid histopathological diagnosis (MILLER \& CAMPBELL, 1984). Additionally, branching right-angled hyphae are considered as diagnostic for $\boldsymbol{P}$. insidiosum (MENDOZA et al., 1996). During this report, intralesional hyphae were between $3.5-5.5 \mu \mathrm{m}$ in diameter, septated and, in some cases, hyphae were branching at right angles; these findings are very suggestive of lesions induced by $\boldsymbol{P}$. insidiosum.

In this report, various kunkers were observed within necrotic areas or surrounded by fibrous connective tissue. Kunkers are the hallmark of equine pythiosis and represent an immunological reaction (the Splendore-Hoeppli phenomenon) to the invading agent (MENDOZA et al., 1996). Kunkers are reportedly observed only in equine pythiosis, being absent in the canine, feline, and bovine variant of the disease (MENDOZA et al., 1996). In the second and third cases, there were marked vascular alterations; similar vascular changes were described in horses infected with $\boldsymbol{P}$. insidiosum (MILLER \& CAMPBELL, 1984). Additionally, most hyphae observed in the cases described here were located at the margins of eosinophilic masses, this location is considered characteristic of $\boldsymbol{P}$. insidiosum (MILLER \& CAMPBELL, 1984).

According to the Federal Inspection Service personnel (Personal Communication, ARRUDA JR, 2002), similar granulomatous cutaneous lesions have been previously observed in other horses, but these were not fully investigated. They have indicated that horses submitted for slaughter are not only from the State of Paraná but also from other neighboring States; the cases described in this report were from the States of São Paulo (where equine pythiosis has been previously described) and Paraná (where pythiosis is not well known). We have diagnosed pythiosis in four horses within a period of 90 days, thus the actual occurrence of equine pythiosis in Northern Paraná may be more frequent than has been reported. The relatively low occurrence of equine pyhtiosis diagnosed in the State of Paraná may be due to the unknown existence of this disease by most practicing large animal veterinarians or that it is being inadvertently confused with other cutaneous lesions such as exuberant granulation tissue, cutaneous habronemiasis, tumors, and other mycotic infections (MILLER \& CAMPBELL, 1984; MENDOZA et al., 1996).

\section{PERSONAL COMMUNICATION}

ARRUDA, H. N. Médico Veterinário, Serviço de Inspeção Federal, Frigorífico Santa Fé, Santa Fé, PR, 2002. E-mail: frigorificosantefe@kfnet.com.br

\section{REFERENCES}

BENTINCK-SMITH, J. et al. Canine pythiosis - isolation and identification of Pythium insidiosum. Journal of Veterinary Diagnostic Investigation, v.1, p.295-298, 1989.

CHAFFIN, M.K.; SCHUMACHER, J.; McMULLAN, W.C. Cutaneous pythiosis in the horse. Veterinary Clinics of North America: Equine Practice, v.11, n.1, p.91-103, 1995.

LEAL, A.B.M. et al. Pitiose eqüina no Pantanal brasileiro: aspectos clínico-patológicos de casos típicos e atípicos. Pesquisa Veterinária Brasileira, v.21, n.4, p.151-156, 2001 a.

LEAL, A.T. et al. Pitiose. Ciência Rural, v.31, n.4, p.735743, $2001 \mathrm{~b}$.

MENDOZA, L.; AJELLO, L.; McGINNIS, M.R. Infections caused by the oomycetous pathogen Pythium insidiosum. Journal of Mycology Médica, v.6, p.151-164, 1996.

MILLER, R.I.; CAMPBELL, R.S.F. The comparative pathology of equine cutaneous phycomycosis. Veterinary Pathology, v.21, p.325-332, 1984.

PIER, A.C. et al. Prominent animal mycoses from various regions of the world. Medical Mycology, v.38, supl. 1, p.4758,2000 .

REIS, JÚNIOR, J.L.; NOGUEIRA, R.H.G. Estudo anatomopatológico e imunoistoquímico da pitiose em eqüinos naturalmente infectados. Arquivo Brasileiro de Medicina Veterinária e Zootecnia, v.54, n.4, p.358-365, 2002. 
SANTURIO, J.M. et al. Cutaneous Pythiosis insidiosi in calves from the Pantanal region of Brazil. Mycopathology, v.141, p.123-125, 1998.

THITITHANYANONT, A. et al. Use of immunotherapeutic vaccine to treat life-threatening human arteritic infection caused by Pythium insidiosum. Clinical Infectious Diseases, v.27, p.1394-1400, 1998.

THOMAS, R.C.; LEWIS, D.T. Pyhtiosis in dogs and cats. The Compendium of Continuing Education for the Practicing Veterinarian, v.20, n.1, p.63-74, 1998. 